\title{
Between Old Lessons and New Challenges
}

\author{
Fyodor A. Lukyanov
}

The year 2019 is a year of landmark anniversaries: a centenary of the VersaillesWashington world order; the 90th anniversary of the Great Depression, which reverberated throughout the 20th century; the 80th anniversary of World War II; the 70th anniversary of the nuclear parity and NATO, the start of the Cold War confrontation; the 40th anniversary of the Islamic Revolution in Iran; the 30th anniversary of changes in Eastern Europe; and the 20th anniversary of NATO's war against Yugoslavia.

All these very different events became milestones in international relations, and each left its own mark on further developments. Their lessons draw increased attention because we are also living through a watershed period. Last year vividly proved that the previous world order had outlived itself and there is no return to it. Time will show what a new one will be like.

The articles contributed to this issue touch upon some of the most painful political problems of our time. Our purpose is to try and understand what place
Russia can take in the new world configuration as it is about to start its own transformation.

Larisa Deriglazova addresses an issue which has been debated in Russia for over three hundred years, namely, relations with Europe and whether their current state reflects Russia's long-term departure from genuine European identity. Boris Mezhuyev presents the conception of "civilizational realism" as a means of finding a proper way to assess the possible and the impossible in Russia's foreign policy. This is important because Russia has so far been unable to break free of captivity by the imagined West and East.

Nicolai Petro sums up the results of the first five years after Ukraine's Maidan. New people came to power in Kiev in February 2014, but the country remains mired in debt, corruption, and strife. The author turns to classical Greek tragedy to analyze the reasons behind Ukraine's persistent failure to achieve social stability. He offers a pessimistic outlook for Ukraine which is building its ethnic identity not on dialogue and reconcili- 
ation but on aggressive alienation from Russia. Dmitry Bunevich analyzes the experience of Ukraine's neighbor, Poland. In his opinion, Polish political circles have been trapped for centuries in "strategic Thanatos," whereby efforts to increase the country's strategic capabilities make it more vulnerable in the long term. This serves as a reminder for Ukraine but should also caution Russia about attempts to reproduce old recipes at a time of dramatic global changes.

Ivan Safranchuk studies RussianAmerican relations which appear to be the most difficult subject for sober analysis. The political storm in the U.S., with Russia happening to be at its center, Donald Trump's personality, the legacy of the twentieth century confrontation, big but largely inapplicable in the current situation, and Russias painful U.S.-centrismall this is poisoning the bilateral atmosphere. The author points to what he views as a systemic cause of the current crisis. Two key parameters of interaction-practical and ideational - as a rule have been in opposition to each other: ideological contradictions could get along with pragmatic approaches in addressing concrete problems, while ideological rapprochement helped soothe frictions although it did not generate pragmatism. But today all is going down on both tracks, and no one really knows how to stop this avalanche.

Maxim Suchkov and Andrei Sushentsov also examine the Russian-American knot, but they are a bit more optimis- tic. They believe that continued contacts and interaction on a narrow range of issues of mutual interest will eventually help overcome the unprecedented downward trend. The authors see one of its causes in the fact that the experience of the second half of the twentieth century cannot be applied to the current situation, which is entirely different from the past one.

\section{Alexander Gabuev and Ivan Zuenko} study the extensive discussion of relations with China and particularly its Belt and Road initiative. Russia has no clearcut position on the issue, but developing a comprehensive approach is an essential prerequisite for the success of Russia's ongoing turn to the East. Robert Manning ponders over another important construct that is crucial for the future of Asia-America's Indo-Pacific concept. Its development will affect Russia's perception of Asia as well.

The Interview section features a conversation with historian Sergei Solovyov who shares his thoughts about Stalinism, one of the most sinister phenomena in the twentieth century, de-Stalinization attempts in Soviet and post-Soviet times, and their impact on left-wing ideas in Russia and the world.

The year 2019 is likely to be disquieting but extremely interesting for observers. The lessons of history and severe present-day challenges meet and produce something new, but the resulting changes may be very different from what we would like to see. 